\title{
Effect of pregrazing herbage mass and pasture allowance on the lactation performance of Holstein-Friesian dairy cows
}

\author{
M. McEvoy, ${ }^{\star} \dagger$ M. O’Donovan, ${ }^{* 1}$ E. Kennedy, ${ }^{\star}$ J. P. Murphy, ${ }^{\star}$ L. Delaby, $\ddagger$ and T. M. Boland† \\ ${ }^{*}$ Dairy Production Research Centre, Teagasc, Moorepark, Fermoy, Co. Cork, Ireland \\ †School of Agriculture, Food Science and Veterinary Medicine, University College Dublin, Belfield, Dublin 4, Ireland \\ łInstitut National de la Recherche Agronomique, Unité Mixte de Recherche, Production du Lait, 35590 St-Gilles, France
}

\section{ABSTRACT}

The objective of this study was to investigate the effect of pregrazing herbage mass (HM) and pasture allowance (PA) on the grazing management and lactation performance of spring-calving dairy cows. Sixty-eight Holstein-Friesian dairy cows (mean calving date, February 6) were randomly assigned across 4 treatments $(\mathrm{n}=17)$ in a $2 \times 2$ factorial arrangement. The 4 treatments consisted of 2 pregrazing $\mathrm{HM}(>4 \mathrm{~cm})$ and $2 \mathrm{PA}$ $(>4 \mathrm{~cm}): 1,700 \mathrm{~kg}$ of dry matter $(\mathrm{DM}) / \mathrm{ha}$ (medium, M) or $2,200 \mathrm{~kg}$ of $\mathrm{DM} / \mathrm{ha}$ (high, $\mathrm{H}$ ), and 16 or $20 \mathrm{~kg}$ of pasture $\mathrm{DM} /$ cow per day. The experimental period lasted $30 \mathrm{wk}$. The experimental area was divided into 4 farmlets, with 1 farmlet per treatment. Mean HM throughout the experimental period was $1,767 \mathrm{~kg}$ of $\mathrm{DM} / \mathrm{ha}(\mathrm{M} \mathrm{HM})$ compared with $2,358 \mathrm{~kg}$ of DM/ha (H $\mathrm{HM}$ ). Offering an M HM sward resulted in significantly greater milk protein yield $(+31.7 \mathrm{~g} / \mathrm{d})$ and lower mean body weight $(-12.8 \mathrm{~kg})$. The body condition score change was significantly smaller $(-0.21)$ with the $\mathrm{M}$ HM treatments compared with the H HM treatment $(-0.34)$. Milk solids output per hectare was $6 \%$ greater on the M HM treatments compared with the $\mathrm{H}$ HM treatments. Increasing PA significantly increased milk $(+0.9 \mathrm{~kg} / \mathrm{d})$, solids-corrected milk $(+0.7 \mathrm{~kg} / \mathrm{d})$, protein $(+43.9 \mathrm{~g} / \mathrm{d})$, and lactose $(+52.7 \mathrm{~g} / \mathrm{d})$ yields. Mean body weight was also significantly greater for cows offered $20 \mathrm{~kg}$ of PA $(+11.4 \mathrm{~kg} / \mathrm{cow})$. It was concluded that in rotational grazing systems, adapting the concept of grazing M HM pastures (1,700 kg of DM/ha) will result in increased sward quality and increased milk solids output per hectare. At medium levels of pregrazing HM, offering animals $20 \mathrm{~kg}$ of DM PA will result in increased milk yield per cow.

Key words: herbage mass, pasture allowance, dairy cow, grazing

Received April 29, 2008.

Accepted September 1, 2008.

${ }^{1}$ Corresponding author: michael.odonovan@teagasc.ie

\section{INTRODUCTION}

Increasing production costs and falling farm-gate product prices have induced a transformation in grassland management practices in recent years. With future feed costs projected to rise, increasing the proportion of grazed grass in the diet of the lactating cow is a major objective for the Irish dairy industry. Dillon et al. (2005) has shown that a $10 \%$ increase in the proportion of grazed grass in the feeding system will reduce the cost of milk produced by 2.5 cents/L. High daily intakes of highly digestible pasture are required to maximize milk yield per cow (Mayne et al., 1987). Intensive pasture-based systems produce less milk per cow compared with confinement systems, instead focusing on high milk output per hectare at reduced costs (Dillon et al., 2005). The main factors affecting milk yield of the grazing dairy cow include herbage mass $(\mathbf{H M})$, pasture allowance (PA), grazing management, and supplementation (Combellas and Hodgson, 1979; Peyraud et al., 1996). Stocking rate is considered the primary driver of milk output per hectare and of profitability in grazing systems (Castle et al., 1972).

In recent years, most interest has been focused on identifying the effect of PA on milk production and grass DMI (Dalley et al., 1999; Kennedy et al., 2007). As the quantity of PA offered increases, the amount of refused pasture increases, and this will lead to a decrease in herbage quality in subsequent grazing rotations. Stakelum and Dillon (2007) reported increased selection of more digestible herbage and green leaf content with greater milk yield on severely grazed swards in comparison with laxly grazed swards. Mayne et al. (1987) reported that low grazing pressure will significantly reduce the OM digestibility (OMD) of swards from mid-June onward. Pasture allowance alone is not the most important factor influencing intake and milk production in grazing dairy cows (Hoogendoorn et al., 1992). Holmes et al. (1992) reported that high HM swards have less digestibility than low HM swards, and at a common PA, milk yield per cow will be depressed with high HM swards. Several short-term studies have 
investigated the relationship between DMI and HM on milk production (Combellas and Hodgson, 1979; Wales et al., 1999).

As the amount of HM increases, the number of grazing days per hectare also increases. This, in theory, should result in increased performance per hectare. However, the increased amounts of stem and dead material in high HM swards will reduce the overall quality of the pasture available to the animals. One method to overcome this is to shorten the rotation length and hence increase the number of rotations, thereby avoiding excessive buildup of HM, increasing sward utilization, and grazing a superior-quality pasture.

The long-term effects of HM on milk output and grass production must be investigated to identify the optimum amount of HM to maintain across the main grazing season. In rotational grazing systems, rapid changes in sward conditions can occur, which affect how plant and animal factors influence production (Combellas and Hodgson, 1979). The effect of HM and allowance on milk production is likely to vary as the season progresses because of changes in the sward structure and regrowth intervals. An understanding of how HM and PA interact to affect sward structure and grazing severity across the grazing season, and hence to influence milk yield, grazing management, and output per hectare, is essential to successfully manage a grazing dairy system. The objective of this experiment was to investigate the cumulative effects of HM and PA on milk yield, output per hectare, and herbage production across the grazing season on spring-calving dairy cows.

\section{MATERIALS AND METHODS}

The experiment was conducted at Moorepark Dairy Production Research Centre, Fermoy, Co. Cork, Ireland $\left(50^{\circ} 09^{\prime} \mathrm{N} ; 8^{\circ} 16^{\prime} \mathrm{W}\right)$. The soil type was free-draining acid brown earth of sandy loam-to-loam texture. The area used was under permanent pasture with a predominantly perennial ryegrass sward (Lolium perenne L.). The swards were on average $5 \mathrm{yr}$ old. Three late-heading diploid cultivars ('Twystar', 'Cornwall', and 'Gilford') were initially sown.

\section{Treatments and Experimental Design}

The experiment investigated the effect of offering 2 levels of pregrazing HM (1,700 and 2,200 kg of DM/ha) and 2 levels of PA (16 or $20 \mathrm{~kg}$ of herbage DM/cow per day), resulting in 4 grazing treatments. The experiment was a randomized block design with a $2 \times 2$ factorial arrangement of treatments. Treatments were imposed for a 30-wk period from April 4 to November 4, 2007.

\section{Animals}

The experimental cows grazed in one large herd from calving and were offered $4 \mathrm{~kg}$ of concentrate. In the week preceding the experiment, the concentrate was reduced gradually and removed from the diet on the day before the experiment commenced. Sixty-eight Holstein-Friesian dairy cows (20 primiparous and 48 multiparous) were selected and balanced by calving date (February 6; SD 14.7 d), lactation number (2.8; SD 1.77), and the following data, which were collected during wk 2 and 3 of lactation: preexperimental milk yield (28.0; SD $4.25 \mathrm{~kg}$ ), BW (512; SD $63.6 \mathrm{~kg}$ ), and BCS on a scale of 1 to 5 (2.8; SD 0.41). Animals were randomly assigned into 1 of 2 herds $(\mathrm{n}=34)$ and were offered 1 of $2 \mathrm{HM}$ : 1,700 $\mathrm{kg}$ of DM/ha (medium, M) or $2,200 \mathrm{~kg}$ of $\mathrm{DM} / \mathrm{ha}$ (high, $\mathbf{H} ;>4 \mathrm{~cm}$ ). These 2 herds were further subdivided into 2 herds $(\mathrm{n}=17)$ and were offered 1 of $2 \mathrm{PA}$ : 16 or $20 \mathrm{~kg}$ of DM/cow per day. This resulted in 4 experimental treatments: M16 (M HM; $16 \mathrm{~kg}$ of PA), M20 (M HM; $20 \mathrm{~kg}$ of PA), H16 (H HM; $16 \mathrm{~kg}$ of PA), and $\mathbf{H 2 0}$ (H HM; $20 \mathrm{~kg}$ of PA). No concentrate was offered during the experimental period.

\section{Grazing Management}

The experimental grazing area comprised 21.3 ha, divided into 10 paddocks. Five paddocks were assigned to the H HM treatments and 5 paddocks were assigned to the M HM treatments. The entire experimental area was grazed once during the preexperimental period (February 19 to April 3). During the preexperimental period, the differences in pregrazing HM were created by varying the time period between initial grazing and applying the experimental grazing treatment, with the H HM pasture grazed initially, followed by the M HM pasture, thus creating different regrowth intervals. All paddocks were grazed to a similar postgrazing height of approximately $4 \mathrm{~cm}$ during the preexperimental period. Paddocks were divided into 2 subpaddocks and permanently fenced. Subpaddocks were randomly assigned to a PA treatment, with 5 subpaddocks per treatment. A similar grazing area (farmlet) was available to each treatment (5.3 ha/treatment). The experimental area for each treatment was managed independently of all other treatments. The first 3 subpaddocks grazed per treatment were grazing-only paddocks. The remaining 2 subpaddocks per treatment were conserved as silage when deemed necessary to control pregrazing HM. The first subpaddock grazed by each treatment was referred to as the base paddock. If animals were in a grazingonly paddock when the base paddock reached target HM, they finished the rotation in that paddock and returned to the base paddock to commence a new rota- 
tion. If animals were in a silage paddock when the base paddock reached target HM, they were returned immediately to the base paddock. Silage paddocks were cut immediately to ensure that the regrowth interval was similar for grazed and ungrazed paddocks. The area conserved for silage was excluded from the calculation of mean stocking rate (SR). Fresh pasture was allocated to each individual herd on a daily basis after the morning milking. No access to the grazing area from the previous day was allowed. Paddocks were dusted daily during April and May with calcined magnesite to prevent hypomagnesemia. Pastures were not topped during the experiment. In late autumn, pregrazing HM was allowed to increase to ensure that adequate pasture was available to the animals to continue grazing until November, with a mean difference of $500 \mathrm{~kg}$ of DM/ha maintained between the $\mathrm{M}$ and $\mathrm{H}$ HM swards. Nitrogen fertilization was similar for each treatment, with a total of $250 \mathrm{~kg}$ of nitrogen/ha applied to each farmlet. Nitrogen was applied after each grazing.

\section{Sward Measurements}

HM Determination. Pasture HM ( $>4 \mathrm{~cm}$ ) was calculated by cutting 4 strips $(1.2 \times 10 \mathrm{~m})$ per treatment area twice weekly with an Agria mower (Etesia UK Ltd., Warwick, UK). Ten grass height measurements were recorded before and after harvesting on each cut strip by using an electronic plate meter (Urban and Caudal, 1990) with a plastic plate $(30 \times 30 \mathrm{~cm}$ and $4.5 \mathrm{~kg} / \mathrm{m}$; Agrosystèmes, Choiselle, France). All mown herbage from each strip was collected, weighed, and subsampled (approximately $0.5 \mathrm{~kg}$ ). A further subsample of $0.1 \mathrm{~kg}$ fresh weight of the herbage sample was dried for $16 \mathrm{~h}$ at $90^{\circ} \mathrm{C}$ for DM determination. Based on the above measurements, it was possible to calculate mass of herbage per centimeter $[\mathrm{HM}(\mathrm{DM} / \mathrm{ha}) \div$ (precutting height - postcutting height); $\mathrm{kg}$ of DM/cm per hectare].

Pasture growth ( $\mathrm{kg}$ of $\mathrm{DM} / \mathrm{ha}$ per day) was calculated by dividing the pasture production figure by the number of days of regrowth. The effect of treatment on grazing management (rotation length, SR, milk output/ ha) was calculated by rotation according to the method of Hoden et al. (1986).

Pre- and Postgrazing Sward Heights. Pregrazing pasture height was measured daily throughout the experimental period by recording approximately 30 heights per treatment across the 2 diagonals of each paddock $(\mathrm{n}=4)$ by using the electronic plate meter. The PA for each herd was calculated by multiplying pregrazing pasture height $(>4 \mathrm{~cm})$ by mass of herb- age $/ \mathrm{cm}$. After grazing, postgrazing sward heights were also recorded for each treatment $(\mathrm{n}=4)$, as described previously.

Herbage Utilization. Herbage mass utilization ( $>4$ $\mathrm{cm})$ was calculated according to the method described by Delaby and Peyraud (1998). Pasture removed was calculated as [(pregrazing sward height - postgrazing sward height $) \times \mathrm{HM} / \mathrm{cm} \times($ area grazed/cow per day $)$; $\mathrm{kg}$ of $\mathrm{DM} / \mathrm{cow}$ per day; $>4 \mathrm{~cm}]$.

\section{Chemical Analysis}

Pasture, representative of that selected by the 4 treatments, was sampled weekly throughout the experiment $(\mathrm{n}=4)$ by using a Gardena hand shears (Accu 60, Gardena International GmbH, Ulm, Germany) after close observation of the defoliation height of the previous treatment. Samples were stored at $-20^{\circ} \mathrm{C}$ before being freeze-dried and milled through a $1-\mathrm{mm}$ sieve before chemical analysis. The pasture samples were analyzed for ADF and NDF (Ankom Technology, Macedon, NY); ash and CP content (Leco FP-428, Leco Australia Pty Ltd., Castle Hill, New South Wales, Australia); and OMD (Fibertec Systems, Foss, Ballymount, Dublin, Ireland).

\section{Animal Measurements}

Milk Production. Milking took place at 0700 and $1600 \mathrm{~h}$ daily. Individual milk yields ( $\mathrm{kg}$ ) were recorded at each milking (Dairymaster, Causeway, Co. Kerry, Ireland). Milk fat, protein, and lactose concentrations were calculated weekly from one successive evening (Tuesday) and morning (Wednesday) milking sample for each animal. A MilkoScan 203 instrument (DK3400, Foss Electric, Hillerød, Denmark) was used to determine the concentrations of these constituents in the milk. Solids-corrected milk yield was calculated by using the equation of Tyrrell and Reid (1965).

$\boldsymbol{B} \boldsymbol{W}$ and $\boldsymbol{B C S}$. Body weight was recorded weekly by using an electronic portable weighing scale and the Winweigh software package (Tru-test Limited, Auckland, New Zealand). Body condition score was recorded every 2 wk throughout the experimental period. Body condition was scored by one experienced independent observer throughout the experiment on a scale of 1 to 5 , (1 = emaciated, $5=$ extremely fat $)$ with increments of 0.25 (Lowman et al., 1976). Body weight and BCS changes were calculated by subtracting the mean of the last 2 wk of the experimental period from the mean of the first 2 wk of the experimental period for the relevant measurement. 
Table 1. Main climatic data during the experiment compared with the previous 10-yr average

\begin{tabular}{llccccccc}
\hline & & \multicolumn{8}{c}{ Month } \\
\cline { 3 - 8 } Item & Year & April & May & June & July & August & September & October \\
\hline Rainfall, mm & 2007 & 17 & 56 & 105 & 112 & 95 & 48 & 39 \\
\multirow{2}{*}{ Mean temperature, ${ }^{\circ} \mathrm{C}$} & $1997-2006$ & 74 & 73 & 68 & 44 & 91 & 94 & 123 \\
& 2007 & 10.9 & 11.5 & 13.8 & 14.6 & 15.1 & 13.2 & 11.5 \\
& $1997-2006$ & 8.9 & 11.5 & 13.9 & 15.7 & 15.9 & 13.8 & 11.1 \\
\hline
\end{tabular}

\section{Statistical Analyses}

All statistical analyses were carried out by using SAS software (SAS Institute, 2005). All sward measurements were analyzed by ANOVA. Herbage data were analyzed by using the following model:

$$
\mathrm{Y}_{i j k}=\mu+\mathrm{H}_{i}+\mathrm{D}_{j}+\mathrm{R}_{k}+\mathrm{R}_{k}\left(\mathrm{~W}_{j}\right)+\mathrm{H}_{i} \times \mathrm{D}_{j}+\mathrm{e}_{i j k},
$$

where $\mu$ is the mean; $\mathrm{H}_{i}$ is the $\mathrm{HM}(i=1$ to 2$) ; \mathrm{D}_{j}$ is the $\mathrm{PA}(j=1$ to 2$) ; \mathrm{R}_{k}$ is the rotation ( $k=1$ to 10$) ; \mathrm{R}_{k}\left(\mathrm{~W}_{j}\right)$ is the week within rotation $(j=1$ to 30$) ; \mathrm{H}_{i} \times \mathrm{D}_{j}$ is the interaction between pregrazing $\mathrm{HM}$ and $\mathrm{PA}$; and $\mathrm{e}_{i j k}$ is the residual error term.

Two cows on the M20 treatments were removed from the experiment (at wk 12 and 17, respectively) because of health problems unrelated to the treatment. These animals were replaced with nonexperimental cows to achieve a constant grazing pressure. Data collected on these animals was not used for statistical analyses. Animal variables were analyzed as 66 individual variables by covariate analysis. Daily milk yield, milk composition, milk constituent yield, BW, and BCS were analyzed for each period with the following model:

$$
\mathrm{Y}_{i j k}=\mu+\mathrm{P}_{i}+\mathrm{H}_{i}+\mathrm{D}_{j}+\mathrm{H}_{i} \times \mathrm{D}_{j}+\mathrm{b}_{1} \mathrm{X}_{i j k}+\mathrm{e}_{i j k},
$$

where $\mathrm{Y}_{i j k}$ represents the response of animal $k$ offered $\mathrm{HM} i$ and $\mathrm{PA} j ; \mu$ is the mean; $\mathrm{P}_{i}$ is parity; $\mathrm{H}_{i}$ is $\mathrm{HM}(i=$
1 to 2$) ; \mathrm{D}_{j}$ is $\mathrm{PA}(j=1$ to 2$) ; \mathrm{H}_{i} \times \mathrm{D}_{j}$ is the interaction of $\mathrm{HM} \times \mathrm{PA} ; \mathrm{b}_{1} \mathrm{X}_{i j k}$ is the respective preexperimental variable; and $\mathrm{e}_{i j k}$ is the residual error term.

\section{RESULTS}

During the experiment, total rainfall (Table 1) in April and October was 77 and $32 \%$, respectively, below the 10-yr average. Rainfall in June and July was 54 and $155 \%$, respectively, above the 10-yr average. Mean daily temperatures were similar to the 10 -yr average except in April, when recorded temperatures were above the 10-yr average.

The chemical composition and nutritive value of the herbage selected by the animals is shown in Table 2 . Medium HM pastures had greater ash $(+6.1 \mathrm{~g} / \mathrm{kg}$ of $\mathrm{DM}), \mathrm{CP}(+47.4 \mathrm{~g} / \mathrm{kg}$ of DM$)$, and OMD $(+14.2 \mathrm{~g} /$ $\mathrm{kg}$ of $\mathrm{DM}$ ) values compared with $\mathrm{H} \mathrm{HM}$ swards (71.3, 199.9 , and $841.3 \mathrm{~g} / \mathrm{kg}$ of DM, respectively). Medium HM pastures had less NDF $(P<0.001 ;-16.3 \mathrm{~g} / \mathrm{kg}$ of DM) compared with the H HM pastures $(413.3 \mathrm{~g} / \mathrm{kg}$ of DM). Figure 1 presents the effect of HM on the OMD value of the selected herbage throughout the main grazing season.

\section{Grass and Grazing Management}

The effect of treatment on grazing management and output per hectare is shown in Table 3 . The first experi-

\begin{tabular}{|c|c|c|c|c|c|c|c|c|}
\hline \multirow[b]{2}{*}{ Item } & \multicolumn{2}{|c|}{1,700} & \multicolumn{2}{|c|}{2,200} & \multirow[b]{2}{*}{$\mathrm{SED}^{2}$} & \multicolumn{3}{|c|}{$P$-value } \\
\hline & 16 & 20 & 16 & 20 & & HM & PA & $\mathrm{HM} \times \mathrm{PA}$ \\
\hline $\begin{array}{l}\text { DM, \% } \\
\text { DM composition. } \%\end{array}$ & 19.0 & 19.1 & 18.9 & 19.1 & - & - & - & - \\
\hline OM digestibility & $85.5^{\mathrm{a}}$ & $85.6^{\mathrm{a}}$ & $84.1^{\mathrm{b}}$ & $84.2^{\mathrm{b}}$ & 0.42 & $<0.001$ & 0.88 & 0.92 \\
\hline $\mathrm{CP}$ & $24.5^{\mathrm{a}}$ & $24.9^{\mathrm{a}}$ & $20.3^{\mathrm{b}}$ & $19.5^{\mathrm{b}}$ & 0.80 & $<0.001$ & 0.70 & 0.32 \\
\hline $\mathrm{ADF}$ & 27.1 & 26.7 & 27.0 & 26.5 & 0.64 & 0.66 & 0.30 & 0.93 \\
\hline NDF & $40.1^{\mathrm{ab}}$ & $39.2^{\mathrm{a}}$ & $41.2^{\mathrm{b}}$ & $41.3^{\mathrm{b}}$ & 0.89 & $<0.01$ & 0.53 & 0.45 \\
\hline Ash & $7.7^{\mathrm{a}}$ & $7.7^{\mathrm{a}}$ & $7.1^{\mathrm{b}}$ & $7.1^{\mathrm{b}}$ & 0.20 & $<0.001$ & 0.82 & 0.97 \\
\hline
\end{tabular}

Table 2. Chemical composition of selected pasture samples during the experiment ${ }^{1}$

a,b Means within a row with different superscripts differ $(P<0.05)$.

${ }^{1}$ Herbage mass (HM) of 1,700 or $2,200 \mathrm{~kg}$ of DM/ha, and pasture allowance (PA) of 16 or $20 \mathrm{~kg}$ of DM/cow per day.

${ }^{2} \mathrm{SED}=\mathrm{SE}$ of the difference 
Table 3. Effect of pregrazing herbage mass (HM; 1,700 or 2,200 $\mathrm{kg}$ of DM/ha) and daily pasture allowance (PA; 16 or $20 \mathrm{~kg}$ of $\mathrm{DM} /$ cow per day) on output per hectare (215-d grazing season)

\begin{tabular}{lccccc}
\hline & \multicolumn{2}{c}{1,700} & & \multicolumn{2}{c}{2,200} \\
\cline { 2 - 3 } \cline { 5 - 6 } Item & 16 & 20 & & 16 & 20 \\
\hline Rotations, $\mathrm{n}$ & 10 & 10 & & 7 & 7 \\
Mean rotation length, d & 21.5 & 21.5 & & 30.7 & 30.7 \\
Area offered, $\mathrm{m}^{2}$ per cow/d & 102 & 113 & & 75 & 83 \\
Daily grass growth, $\mathrm{kg}$ of DM/ha per day & 67.6 & 75.7 & & 65.9 & 71.6 \\
Grazing days per hectare, d/ha & 956 & 869 & & 927 & 817 \\
Average stocking rate, cows/ha & 4.45 & 4.04 & & 4.31 & 3.80 \\
Milk yield per hectare, $\mathrm{kg}$ & 17,560 & 16,461 & & 17,579 & 15,786 \\
\hline
\end{tabular}

mental grazing rotation began on April 4 and ranged in duration from $19 \mathrm{~d}$ for the M20 treatment to $27 \mathrm{~d}$ for the H16 treatment, with the M16 and H20 treatments being intermediate (20 and $26 \mathrm{~d}$, respectively). The mean rotation length was $21 \mathrm{~d}$ for the M HM and $31 \mathrm{~d}$ for the H HM treatments. Ten rotations were completed by the M HM treatments and 7 were completed by the $\mathrm{H}$ HM treatments. The total area conserved for silage was 4.24 (M16), 3.65 (M20), 2.25 (H16), and 1.73 ha (H20). The mean SR was 4.5 (M16), 4.0 (M20), 4.3 (H16), and 3.8 cows/ha (H20). The effect of treatment on pasture measurements is shown in Table 4. Pregrazing HM for the M HM treatment was less $(P<0.001 ;-591 \mathrm{~kg}$ of $\mathrm{DM} / \mathrm{ha})$ than for the $\mathrm{H}$ HM treatment $(2,358 \mathrm{~kg}$ of $\mathrm{DM} / \mathrm{ha})$. Mass of herbage per centimeter was greater $(P<0.05 ;+5 \mathrm{~kg}$ of $\mathrm{DM} / \mathrm{cm}$ per hectare $)$ for the $\mathrm{H} \mathrm{HM}$ swards than for the M HM swards $(204 \mathrm{~kg}$ of DM/cm per hectare). Mass of herbage per centimeter for the 20$\mathrm{kg}$ PA swards was greater $(P<0.001 ;+8 \mathrm{~kg}$ of DM $/ \mathrm{cm}$ per hectare) than for the $16-\mathrm{kg}$ PA swards (202 kg of $\mathrm{DM} / \mathrm{cm}$ per hectare). Animals on the M HM treatment were offered a larger area $\left(P<0.001 ;+29.8 \mathrm{~m}^{2} /\right.$ cow per day) compared with animals on the H HM treatment $\left(79.8 \mathrm{~m}^{2} /\right.$ cow per day). The mean grazing area offered to animals on the $20-\mathrm{kg}$ treatment was larger $(P$ $<0.001 ;+9.7 \mathrm{~m}^{2} /$ cow per day) than the area offered to animals on the $16-\mathrm{kg}$ treatment $\left(89.8 \mathrm{~m}^{2} /\right.$ cow per day).
Postgrazing sward height ranged from $4.3 \mathrm{~cm}$ (M16) to $5.4 \mathrm{~cm}(\mathrm{H} 20 ; P<0.001$; Table 5$)$. Cows offered the $20-\mathrm{kg}$ PA had consistently greater postgrazing sward heights than those offered the $16-\mathrm{kg}$ PA. The mean increase in postgrazing sward height was $0.25 \mathrm{~cm} / \mathrm{kg}$ of pasture offered. Cows offered the 20-kg PA removed more pasture $(P<0.001 ;+2 \mathrm{~kg})$ than cows offered the $16-\mathrm{kg}$ PA (15.6 kg/cow per day).

\section{Animal Performance}

Milk production results of the experiment are shown in Table 5. Cows offered the 20-kg PA had a greater milk yield $(P<0.05 ;+0.95 \mathrm{~kg})$ than cows offered the $16-\mathrm{kg}$ PA $(-0.9 \mathrm{~kg} / \mathrm{cow}$ per day $)$. There was an interaction between HM and PA on milk protein yield. The M20 treatment had the greatest milk protein yield $(P$ $<0.05 ;+67 \mathrm{~g} / \mathrm{d})$ compared with the other treatments, which did not differ $(618 \mathrm{~g} / \mathrm{d})$. Animals offered the 16 $\mathrm{kg}$ PA had a lower milk lactose yield $(P<0.01 ;-53$ $\mathrm{g} / \mathrm{d})$ than cows offered the 20-kg PA (839 g/d). Cows offered the 16-kg PA had lower $(P<0.05 ;-0.6 \mathrm{~kg} / \mathrm{cow}$ per day) SCM yield than those offered the $20-\mathrm{kg}$ PA (17.5 kg/cow per day).

There was a significant interaction $(P<0.01)$ between $\mathrm{HM}$ and PA on mean BW. Animals grazing the M16 treatment had a lower mean BW $(-25.0 \mathrm{~kg})$ than

Table 4. Effect of pregrazing herbage mass (HM; 1,700 or 2,200 $\mathrm{kg}$ of DM/ha) and daily pasture allowance (PA; 16 or $20 \mathrm{~kg}$ of DM/cow per day) on pre- and postgrazing sward height, HM, and herbage utilization during the experiment

\begin{tabular}{|c|c|c|c|c|c|c|c|c|}
\hline \multirow[b]{2}{*}{ Item } & \multicolumn{2}{|c|}{1,700} & \multicolumn{2}{|c|}{2,200} & \multirow[b]{2}{*}{ SED } & \multicolumn{3}{|c|}{$P$-value } \\
\hline & 16 & 20 & 16 & 20 & & HM & $\mathrm{PA}$ & $\mathrm{HM} \times \mathrm{PA}$ \\
\hline $\mathrm{HM}, \mathrm{kg}$ of $\mathrm{DM} / \mathrm{ha}$ & $1,665^{\mathrm{a}}$ & $1,868^{\mathrm{b}}$ & $2,235^{\mathrm{c}}$ & $2,481^{\mathrm{d}}$ & 63.3 & $<0.001$ & $<0.001$ & 0.63 \\
\hline Pregrazing, cm & $12.5^{\mathrm{a}}$ & $13.2^{\mathrm{b}}$ & $15.1^{\mathrm{c}}$ & $15.8^{\mathrm{d}}$ & 0.26 & $<0.001$ & $<0.001$ & 0.93 \\
\hline Postgrazing, cm & $4.3^{\mathrm{a}}$ & $5.1^{\mathrm{b}}$ & $4.3^{\mathrm{a}}$ & $5.4^{\mathrm{c}}$ & 0.06 & $<0.001$ & $<0.001$ & $<0.01$ \\
\hline Herbage removed, $\mathrm{kg} / \mathrm{cow}$ & $15.6^{\mathrm{a}}$ & $17.7^{\mathrm{b}}$ & $15.6^{\mathrm{a}}$ & $17.6^{\mathrm{b}}$ & 0.13 & 0.41 & $<0.001$ & 0.89 \\
\hline
\end{tabular}

${ }^{\mathrm{a}-\mathrm{d}}$ Means within a row with different superscripts differ $(P<0.05)$.

${ }^{1} \mathrm{SED}=\mathrm{SE}$ of the difference. 
Table 5. Effect of pregrazing herbage mass (HM; 1,700 or 2,200 kg of DM/ha) and daily pasture allowance (PA; 16 or $20 \mathrm{~kg}$ of DM/cow per day) on the milk production performance of spring-calving cows during the total experimental period

\begin{tabular}{|c|c|c|c|c|c|c|c|c|}
\hline \multirow[b]{2}{*}{ Item } & \multicolumn{2}{|c|}{1,700} & \multicolumn{2}{|c|}{2,200} & \multirow[b]{2}{*}{$\mathrm{SED}^{1}$} & \multicolumn{3}{|c|}{$P$-value } \\
\hline & 16 & 20 & 16 & 20 & & $\mathrm{HM}$ & PA & $\mathrm{HM} \times \mathrm{PA}$ \\
\hline Fat & 4.07 & 3.98 & 4.13 & 3.97 & 1.18 & 0.76 & 0.15 & 0.73 \\
\hline Protein & 3.41 & 3.47 & 3.41 & 3.45 & 0.68 & 0.90 & 0.30 & 0.85 \\
\hline Lactose & $4.35^{\mathrm{a}}$ & $4.45^{\mathrm{b}}$ & $4.41^{\mathrm{ab}}$ & $4.41^{\mathrm{ab}}$ & 0.40 & 0.73 & 0.10 & 0.10 \\
\hline BW change, kg & 29.7 & 46.1 & 37.4 & 40.9 & 8.30 & 0.83 & 0.11 & 0.29 \\
\hline Average $\mathrm{BCS}^{2}$ & 2.59 & 2.63 & 2.67 & 2.72 & 0.062 & 0.07 & 0.36 & 0.90 \\
\hline BCS change & $-0.22^{\mathrm{a}}$ & $-0.20^{\mathrm{a}}$ & $-0.42^{\mathrm{b}}$ & $-0.26^{\mathrm{ab}}$ & 0.089 & $<0.05$ & 0.17 & 0.31 \\
\hline
\end{tabular}

${ }^{\mathrm{a}, \mathrm{b}}$ Means within a row with different superscripts differ $(P<0.05)$.

${ }^{1} \mathrm{SED}=\mathrm{SE}$ of the difference.

${ }^{2}$ On a scale of 0 to 5 , where $1=$ emaciated and $5=$ extremely fat, using increments of 0.25 .

those in the other treatments $(519.4 \mathrm{~kg})$, between which there was no difference. Increasing HM resulted in a significant increase $(P<0.05)$ in BCS loss. Animals offered the M HM had a mean BCS loss of -0.21 units over the experimental period, compared with -0.34 units for animals offered the H HM treatment.

\section{Output per Hectare}

Production-per-hectare results are shown in Table 3. Grazing days per hectare increased on the M HM $(+40$ d/ha) treatments compared with the H HM treatments (873 d/ha). The 16-kg PA treatments had a greater number of grazing days per hectare $(+99 \mathrm{~d} / \mathrm{ha})$ than the $20-\mathrm{kg}$ PA treatments $(843 \mathrm{~d} / \mathrm{ha})$. Daily pasture growth rates were greater $[P<0.01 ;+2.9 \mathrm{~kg}$ of DM/ ha per day (for the M HM compared with the H HM swards (68.7 kg of DM/ha per day)]. Offering the $20-\mathrm{kg}$ PA resulted in greater pasture growth rates $(P<0.001$; $+6.9 \mathrm{~kg}$ of $\mathrm{DM} /$ ha per day) compared with the $16-\mathrm{kg}$ PA treatments (66.7 $\mathrm{kg}$ of $\mathrm{DM} /$ ha per day).

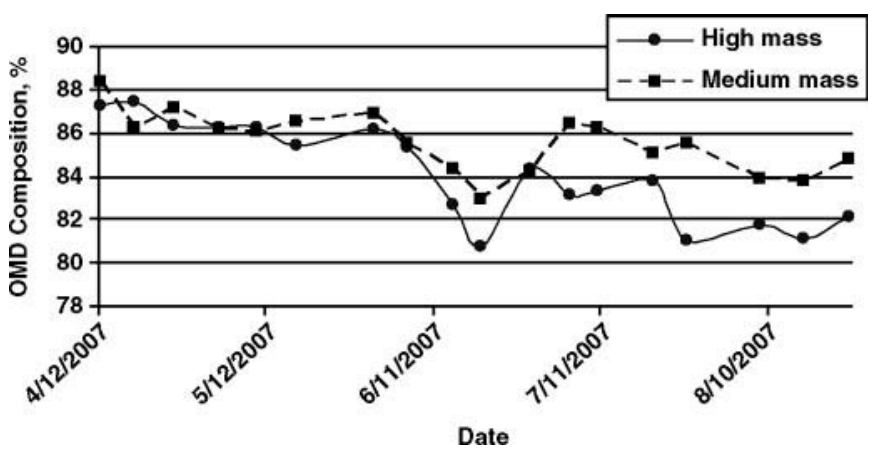

Figure 1. Organic matter digestibility (OMD) of pasture selected by the grazing animals offered swards with medium and high herbage mass.
The total milk yield per grazed hectare on a farmlet basis was greatest for the $16-\mathrm{kg}$ PA treatments at 17,560 $\mathrm{kg}$ (M16) and 17,579 kg (H16), compared with 16,461 and 15,786 kg (M20 and H20, respectively). Milk solids output per hectare was $6 \%$ greater on the M HM than the H HM (1,190 kg of milk solids/ha) treatments.

\section{DISCUSSION}

Many previous experiments describing the effects of $\mathrm{HM}$ on milk production have compared treatments of early- and late-grazed swards, with the experiment beginning when the sward is first grazed (Carton et al., 1989; O'Donovan et al., 2004; Kennedy et al., 2007). In the current study, all swards were grazed once to a similar postgrazing sward height before the experiment commenced to ensure a similar preexperimental treatment of all swards and to avoid differences arising from grazed and ungrazed swards. The extended experimental time period (30 wk) provided an opportunity to assess the cumulative treatment effects on milk and pasture production during the grazing season. Such an experimental approach is vital in grazing studies to establish the longer term effects of grazing management. The objective of this experiment was to investigate the effect of pregrazing HM and daily PA on the milk production performance of spring-calving dairy cows throughout the main grazing season.

\section{Grass Production and Quality}

Despite the significant effect of treatment on the mass of herbage per centimeter, the differences were not biologically significant. Total pasture DM production was reduced with the $16 \mathrm{~kg}$ of $\mathrm{PA}$ treatments. Carton et al. (1989) and Stakelum and Dillon (2007) 
reported an increase in leaf DM production as grazing pressure increased. This suggests that with increased grazing pressure, total pasture DM yield was reduced, whereas the leaf DM proportion tended to increase. Furthermore, the leaf proportion tended to be greatest in low HM swards, resulting in increased OMD values compared with $\mathrm{H}$ HM swards, which tended to have increased stem and dead proportions (L'Huillier, 1988; Hoogendoorn et al., 1992; Stakelum and Dillon, 2007). It has been shown that severe grazing in the early to midsummer period will reduce the ratio of reproductive to vegetative tillers (Hoogendoorn et al., 1992; Hurley, 2007), thereby avoiding large accumulations of stem in the sward, which has a negative impact on pasture quality. Severe grazing, such as that observed with the $16 \mathrm{~kg}$ of PA treatments, reduced the proportion of stem and dead material in midsummer and led to increased midseason sward digestibility and green leaf content (Hurley, 2007). The selected pasture of all swards had similar OMD values until early June. A rapid decline in OMD values was subsequently observed (Figure 1). This reduction in OMD was more pronounced with the H HM swards and coincided with the reproductive phase of the plant. The OMD of the pasture from the M HM swards was consistently greater than that from the H HM swards for the remainder of the season, indicating a better quality sward. Similarly, Jacobs et al. (1998) associated an increasing HM with a decline in DM digestibility and CP, and increased NDF. These differences are likely due to differences in proportions of leaf, stem, and senescent materials in the sward.

\section{Herbage Removed and Utilization}

Several authors have reported decreased DMI at high HM (Hodgson et al., 1977; Combellas and Hodgson, 1979; Peyraud et al., 1996). This contradicts results from the current study, regardless of $\mathrm{HM}(>4 \mathrm{~cm})$; there was no difference in pasture removed per cow for treatments offered similar amounts of PA. The differences in HM in the current study may not have been large enough (600 kg of DM/ha difference between treatments) to negatively affect the proportion of pasture removed. The amounts of PA offered may have been restrictive compared with the amounts offered in other studies, such as that of Peyraud et al. (1996), in which animals were offered up to $40 \mathrm{~kg}$ of $\mathrm{OM}$ daily (from ground level). O'Donovan et al. (2004) reported a mean difference in pasture removed of $2.2 \mathrm{~kg}$ between swards stocked at 5.5 and 4.5 cows/ha across the first and second grazing rotation. This is similar to the mean difference of $1.8 \mathrm{~kg}$ of $\mathrm{DM} /$ cow per day of pasture removed between the $20 \mathrm{~kg}$ of DM (SR of 3.9 cows/ha) and $16 \mathrm{~kg}$ of DM (SR of 4.4 cows/ha) across the grazing season. For each additional kilogram of pasture offered, $0.45 \mathrm{~kg}$ was removed by the animals. This is similar to the $0.43 \mathrm{~kg} / \mathrm{kg}$ of PA offered to early-lactation animals (McEvoy et al., 2007) and $0.34 \mathrm{~kg} / \mathrm{kg}$ of PA offered in the study by Delaby and Peyraud (2003).

The increased amount of pasture removed on the 20 $\mathrm{kg}$ of PA treatments coincided with an $8 \%$ reduction in the utilization $(>4 \mathrm{~cm}$ ) of the pasture offered, compared with treatments offered the $16 \mathrm{~kg}$ of PA (96\%). However, the $16 \mathrm{~kg}$ of PA treatments achieved a greater number of grazing days per hectare (+99 d) compared with the $20 \mathrm{~kg}$ of PA treatments. As the PA offered to the animals was reduced, the SR per hectare could be increased.

\section{Animal Performance}

Holmes et al. (1992) reported increased milk production by cows grazing low HM compared with high HM swards. This contradicts the short-term study of Wales et al. (1999), which reported lower milk production for early-lactation cows on low HM compared with medium HM swards. However, in midlactation with the same animals, there was no effect of HM on animal production; this agrees with the results of the current study. There was no difference in milk production of animals grazing $\mathrm{M}$ or H HM swards, which agrees with the study by O'Donovan et al. (2004). This indicates that with $\mathrm{H}$ HM swards, offering a high PA will not result in improved milk yields. In fact, the cumulative effect of grazing M HM swards became more apparent in the second half of the grazing season, when HM and PA interacted. It is clear that the concept of grazing M HM swards across the grazing season led to enhanced milk production performance in the latter part of the grazing season when the $20 \mathrm{~kg}$ of PA was offered (Figure 2).

Stakelum and Dillon (2007) reported that as grazing pressure was reduced, HM increased and OMD content and leaf proportions decreased. Le Du et al. (1981) suggested that predominantly leafy swards, similar to the M HM sward in the current study, have a low fiber content, which maintains a low acetate:propionate ratio, thus depressing milk fat. In the current study, there was no difference in milk fat concentration between treatments, despite a significant difference in NDF content between the selected pasture of the M and H HM treatments. Stockdale et al. (1987) reported that milk fat concentrations declined when the NDF content in the diet was below $25 \%$. Large variation in the recommended NDF requirements of dairy cows has been reported in the literature, in the range of $25 \%$ (Stockdale et al., 1987) to $40 \%$ (Chamberlain and Wilkinson, 1996). In the current study, the NDF supplied in the diet was at 


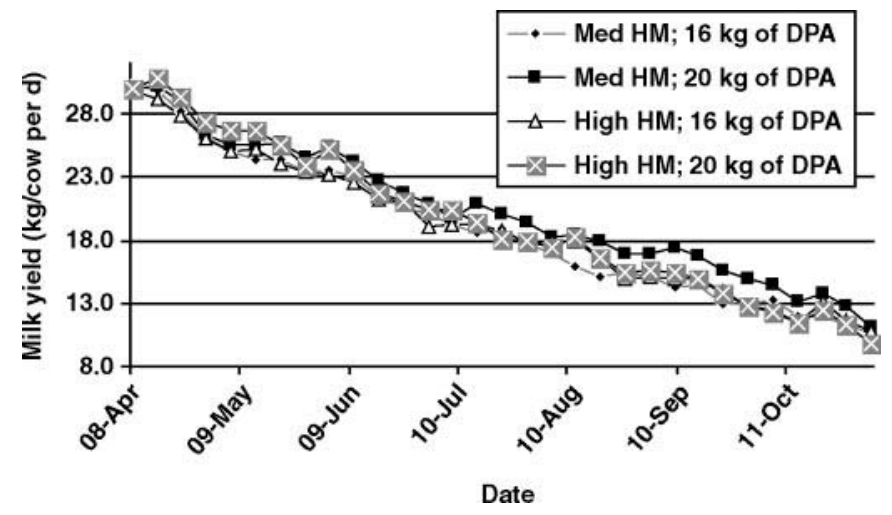

Figure 2. Effect of herbage mass (HM) and pasture allowance on milk production profile across the experimental period. DPA $=$ daily pasture allowance.

the upper limit of recommendations (range: 39 to $41 \%$ ), indicating sufficient fiber available to the animals to support normal rumen function.

The mean milk yield response per kilogram of pasture removed was $0.43 \mathrm{~kg}$, which is lower than the milk response of $1.8 \mathrm{~kg} / \mathrm{kg}$ reported by O'Donovan et al. (2004). The large difference in milk yield response between these 2 studies may be explained by the greater restriction on intake imposed by the SR in the study by O'Donovan et al. (2004). Previous research has shown a greater milk yield response in spring compared with summer (Stockdale, 1999). In the current study, the response was the mean response from April to November for spring-calving cows. The milk response to the extra DM offered was $0.23 \mathrm{~kg} / \mathrm{kg}$ offered, which is similar to the $0.20 \mathrm{~kg} / \mathrm{kg}$ offered reported by Delaby et al. (2001) for midlactation cows. Combellas and Hodgson (1979) and Wales et al. (1999) reported no effect of HM on milk composition, which is in agreement with the results of the current study. In 2 separate experiments lasting less than 3 wk, Hoogendoorn et al. (1992) observed increased protein yield with low HM pastures (2,900 kg of DM/ha) compared with high HM pastures (5,100 kg of DM/ha; > ground level). Although HM had no effect on milk composition in the current study, milk protein yield was significantly greater with the low HM treatment.

\section{Milk Output per Unit Area}

Efficient pasture-based dairy systems are characterized by high milk output per unit of land, compared with confinement systems in which efficiency is characterized by high milk output per cow (Clark and Kanneganti, 1998). Numerous studies have reported that high HM swards support a greater SR, resulting in increased milk production per hectare in short-term experiments (Holmes et al., 1992; O'Donovan et al., 2004; Kennedy et al., 2006). This study shows that the M HM swards managed over the main grazing season (April to October) could support a greater SR and also increase milk production per hectare and milk solids per hectare. This difference occurred because of the improved quality of herbage available to the animal owing to intense grazing of the sward (Hoogendoorn et al., 1992) throughout the season, and the SR that could be maintained on these sward types. The M HM swards achieved a greater number of grazing days per hectare. The effect of HM on individual factors, including SR, grazing days per hectare, milk yield per hectare, and milk solids per hectare, was smaller than that reported in short-term early-lactation studies (Kennedy et al. 2006). However, the accumulation of the benefits from each factor clearly highlights the superiority of grazing M HM swards to optimize the available land to increase output in grazing dairy systems, in which production per hectare is becoming increasingly important. This increase in milk output per hectare $(+6 \%)$ on $\mathrm{M} \mathrm{HM}$ swards highlights the potential to optimize economic performance through grazing management, because it is on this basis that the dairy processor will make payments in the future (Shalloo et al. 2007).

\section{CONCLUSIONS}

The effect of HM and daily PA on sward quality and milk production must be considered to achieve optimal production on a per-cow or per-hectare basis. Results from this experiment indicate that grazing swards at M HM $(1,700 \mathrm{~kg}$ of DM/ha; $>4 \mathrm{~cm})$ increased the milk solids output per hectare and grazing days per hectare relative to grazing cows on $\mathrm{H}$ HM swards. Adapting the concept of grazing lower HM swards resulted in increased pasture quality after the reproductive period of the plants.

\section{ACKNOWLEDGMENTS}

The authors thank M. Feeney, F. Flynn, J. Nash, C. Fleming, and N. Galvin (Dairy Production Research Centre, Moorepark) for their technical assistance. Gratitude is also expressed to all the Moorepark farm staff for their care of the experimental animals and assistance with measurements throughout the study.

\section{REFERENCES}

Carton, O. T., A. J. Brereton, W. F. O'Keeffe, and G. P. Keane. 1989. Effect of turnout date and grazing severity in a rotationally grazed reproductive sward. 2. Tissue turnover. Ir. J. Agric. Res. $26: 165-175$. 
Castle, M. E., E. MacDaid, and J. N. Watson. 1972. Some factors affecting milk production from grassland at the Hannah Institute, 1951-70. J. Br. Grassl. Soc. 27:87-92.

Chamberlain, A. T., and J. M. Wilkinson. 1996. Feeding the Dairy Cow. Chalcombe Publications, Lincoln, UK.

Clark, D. A., and V. R. Kanneganti. 1998. Grazing management systems for dairy cattle. Page 331 in Grass for Dairy Cattle. J. H. Cherney and D. J. R. Cherney, ed. CAB International, Oxon, UK.

Combellas, J., and J. Hodgson. 1979. Herbage intake and milk production by grazing diary cows. 1 . The effects of variation in herbage mass and daily herbage allowance in a short-term trial. Grass Forage Sci. 34:209-214.

Dalley, D. E., J. R. Roche, C. Grainger, and P. J. Moate. 1999. Dry matter intake, nutrient selection and milk production of diary cows grazing rainfed perennial pastures at different herbage allowances in spring. Aust. J. Exp. Agric. 39:923-931.

Delaby, L., and J. L. Peyraud. 1998. Effect d'une reduction simultanée de la fertilisation azotée et du chargement sur les performances des vaches laitières et la valorisation du pâturage. Ann Zootech. $47: 17-39$

Delaby, L., and J. L. Peyraud. 2003. The effect of two contrasting grazing managements and level of concentrate supplementation on the performance of grazing dairy cows. Anim. Res. 52:437-460.

Delaby, L., J. L. Peyraud, and R. Delagarde. 2001. Effect of the level of concentrate supplementation, herbage allowance and milk yield at turn-out on the performance of dairy cows in mid lactation at grazing. Anim. Sci. 73:171-181.

Dillon, P., J. R. Roche, L. Shalloo, and B. Horan. 2005. Optimising financial return from grazing in temperate pastures. Pages 131148 in Utilisation of Grazed Grass in Temperate Animal Systems. Proc. satellite workshop of the XXth Int. Grassl. Congr., Cork, Ireland. J. J. Murphy, ed. Wageningen Academic Publishers, the Netherlands.

Hoden, A., D. Micol, G. Liénard, A. Muller, and J. L. Peyraud. 1986. Interprétation des essais de pâturage avec des bovins: Terminologie, modes de calcul, bilans annuels. Bull. Tech. CRZV Theix 63:3142.

Hodgson, J., J. M. Rodriguez Capriles, and J. S. Fenlon. 1977. The influence of sward characteristics on the herbage intake of grazing calves. J. Agric. Sci. Camb. 89:743-750.

Holmes, C. W., C. J. Hoogendoorn, M. P. Ryan, and A. C. P. Chu. 1992. Some effects of herbage composition, as influenced by previous grazing management, on milk production on ryegrass/ white clover pastures. 1. Milk production in early spring: Effects of different regrowth intervals during the preceding winter period. Grass Forage Sci. 47:309-315.

Hoogendoorn, C. J., C. W. Holmes, and A. C. P. Chu. 1992. Some effects of herbage composition, as influenced by previous grazing management, on milk production by cows grazing on ryegrass/ white clover pastures. 2. Milk production in late spring/summer: Effects of grazing intensity during the preceding spring period. Grass Forage Sci. 47:316-325.

Hurley, G. 2007. Factors controlling reproductive development in Lolium perenne $\mathrm{L}$. and their influence on mid-season sward quality. $\mathrm{PhD}$ Thesis. Queen's University, Belfast, N. Ireland.

Jacobs, J. L., S. E. Rigby, F. R. McKenzie, G. N. Ward, and G. Kearney. 1998. Effect of lock up and harvest dates on dairy pasture dry matter yield and quality for silage in south-western Victoria. Aust. J. Exp. Agric. 38:131-138.
Kennedy, E., M. O'Donovan, J. P. Murphy, F. O'Mara, and L. Delaby. 2007. The effect of initial spring grazing date and subsequent stocking rate on the grazing management, grass dry matter intake and milk production of dairy cows in summer. Grass Forage Sci. 61:375-384.

Kennedy, E., M. O'Donovan, J. P. Murphy, F. P. O'Mara, and L. Delaby. 2006. The effect of initial spring grazing date and subsequent stocking rate on the grazing management, grass dry matter intake and milk production of dairy cows in summer. Grass Forage Sci. 61:375-384.

L'Huillier, P. 1988. Reduced input pasture management options. Pages 19-25 in Proc. Ruakura Farmers Conference, New Zealand.

Le Du, Y. L. P., R. D. Baker, and R. D. Newberry. 1981. Herbage intake and milk production by grazing dairy cows. 3 . The effect of grazing severity under continuous stocking. Grass Forage Sci. 36:307-318.

Lowman, B. G., N. Scott, and S. Somerville. 1976. Condition Scoring of Cattle. Rev. Ed. Bull. No. 6. East of Scotland College of Agriculture, Edinburgh, UK.

Mayne, C. S., R. D. Newberry, S. C. F. Woodcock, and R. J. Wilkins, 1987. Effect of grazing severity on grass utilization and milk production of rotationally grazed dairy cows. Grass Forage Sci. $43: 137-150$

McEvoy, M., M. O'Donovan, J. P. Murphy, F. O'Mara, M. Rath, and L. Delaby. 2007. Comparison of two techniques to estimate herbage intake of grazing dairy cows. Page 110 in Proc. Agric. Res. Forum 2007. Tullamore, Offaly, Ireland.

O'Donovan, M., L. Delaby, and J. L. Peyraud. 2004. Effect of time of initial grazing date and subsequent stocking rate on pasture production and dairy cow performance. Anim. Res. 53:489-502.

Peyraud, J. L., E. A. Comeron, M. H. Wade, and G. Lemaire. 1996 The effect of daily herbage allowance, herbage mass and animal factors upon herbage intake by grazing dairy cows. Ann. Zootech. $45: 201-217$.

SAS Institute. 2005. SAS User's Guide: Statistics. SAS Inst. Inc., Cary, NC.

Shalloo, L., S. O'Donnell, and B. Horan. 2007. Profitable dairying in an increased EU milk quota scenario. Pages 20-44 in Proc. Natl. Dairy Conf., Kilkenny, Ireland. Teagasc, Moorepark, Fermoy, Co. Cork, Ireland.

Stakelum, G., and P. Dillon. 2007. The effect of grazing pressure on rotationally grazed pastures in spring/early summer on subsequent sward characteristics. Ir. J. Agric. Food Res. 46:15-28.

Stockdale, C. R. 1999. The nutritive characteristics of herbage consumed by grazing dairy cows affect milk yield responses obtained from concentrate supplementation. Aust. J. Exp. Agric. 39:379-387.

Stockdale, C. R., A. Callaghan, and T. E. Trigg. 1987. Feeding high energy supplements to pasture fed dairy cows. Effects of stage of lactation and level of supplement. Aust. J. Agric. Res. 38:927940.

Tyrrell, H. F., and J. T. Reid. 1965. Prediction of the energy value of cow's milk. J. Dairy Sci. 48:1215-1233.

Urban, B., and J. P. Caudal. 1990. Herbometre automatise (Automatic platemeter). Pages 57-59 in Les Journées de la Mesure. Électronique, Informatique, Automatique. Port Leucate, France. Institut National de la Recherche Agronomique, Paris, France.

Wales, W. J., P. T. Doyle, C. R. Stockdale, and D. W. Dellow. 1999. Effects of variations in herbage mass, allowance, and level of supplement on nutrient intake and milk production of dairy cows in spring and summer. Aust. J. Exp. Agric. 39:119-130. 